\title{
State Repression of Chinese Labor NGOs: A Chilling Effect?
}

\author{
Ivan Franceschini and Elisa Nesossi*
}

\begin{abstract}
A B S T R A C T
Since their emergence in China in the mid-1990s, labor NGOs have been exposed to a wide array of threats by the Party-state. But under Xi Jinping the repressive strategies of the Chinese authorities have become more sophisticated, with the adoption of new laws and regulations aimed at enforcing state control and efforts to cut the NGOs' access to foreign funding. How do Chinese labor NGO activists cope with these threats? Do the attacks silence them or reinforce their commitment? This article assesses the consequences of repression on two levels: at a subjective level, affecting the outlook and motivations of individual activists, and on an operational level, affecting the priorities and strategies of labor NGOs. We argue that while labor activists are equipped to deal with the "rough" side of repression, the more sophisticated approach recently pursued by Chinese authorities is much more threatening.
\end{abstract}

Apparently, the situation has reached a point of no return. It's the same everywhere in the country, as long as you work on labor issues.

-Chinese labor NGO activist, August 2016

$\mathrm{T}$ he employees of Chinese labor NGOs have grown accustomed to dealing with the suspicions and hostility of the Party-state. Over the years, they have been repeatedly threatened with fines, evictions, broken careers, and arrests. Some have been roughed up and their offices have been raided. In some cases, their family members, no matter how far away, have received ominous visits by officials. Nonetheless, they usually managed to keep their organizations afloat, in the belief that the storm of the moment would abate and that, eventually, they would retain some space to operate. After all, as they argued at every opportunity, by providing legal counseling to the workers they were in effect helping to channel labor dis-

${ }^{*}$ We are thankful for the suggestions of the editors, two anonymous reviewers, Christian Sorace, Nicholas Loubere, and participants at a workshop on labor rights sponsored by the Australian Centre on China in the World.

Electronically published March 23, 2018

The China Journal, no. 80. 1324-9347/2018/8001-0006. Copyright 2018 by The Australian National University. All rights reserved. 
putes through the legal system, thus assisting the Party-state in maintaining social stability, a fact that, in their view, the authorities were surely bound to understand.

However, in the past few years, new repressive methods employed by the government have shaken this confidence of labor NGO employees. Traditionally, labor NGOs in China have focused on three kinds of activities, which they considered relatively safe in the Chinese political context: $(a)$ establishing workers' centers, places that usually include a small library and that offer educational classes and recreational activities; (b) running outreach programs on labor rights, for instance, by distributing leaflets and materials about the Chinese labor law; and (c) conducting social surveys and policy advocacy. ${ }^{1}$ A number of NGOs have also engaged in "rights protection" (weiquan 维权) activities, providing workers with assistance in utilizing legal channels and, occasionally, acting as their representative in resolving labor disputes. ${ }^{2}$ Some others have established collaborations with multinational corporations to carry out occupational health and safety programs and social dialogue inside factories. The focus on activities of this kind has gained Chinese labor NGOs the unflattering label of "anti-solidarity machines"-a term coined by scholars Ching Kwan Lee and Shen Yuan, who have argued that by putting too much emphasis on individual workers' legal rights, these organizations are actually hindering the development of a proper labor movement in China organized around workers' collective rights and interests. ${ }^{3}$

Only in the past few years have a few labor NGOs started to go beyond this approach of helping individual workers mount legal cases by promoting collective bargaining. ${ }^{4}$ While continuing to provide free legal aid and legal training, these organizations have intervened actively in strikes launched by workers, encouraging aggrieved employees to elect their own representatives in order to negotiate collectively with employers. In light of this shift, labor lawyer Duan Yi has argued that Chinese labor NGOs are transforming themselves from being "service-type"

1. Chris King-chi Chan, "Community-Based Organizations for Migrant Workers' Rights: The Emergence of Labour NGOs in China," Community Development Journal 48, no. 1 (2013): 6-22.

2. Yi Xu, "Labor Non-Governmental Organizations in China: Mobilizing Rural Migrant Workers," Lournal of Industrial Relations 55, no. 2 (2013): 243-59.

3. Ching Kwan Lee and Yuan Shen, "The Anti-Solidarity Machine? Labor Nongovernmental Organizations in China," in From Iron Rice Bowl to Informalization: Markets, Workers, and the State in a Changing China, ed. Sarosh Kuruvilla, Ching Kwan Lee, and Mary Gallagher (Ithaca, NY: Cornell University Press, 2011), 173-87.

4. Feng Chen and Xuehui Yang, "Movement-Oriented Labour NGOs in South China: Exit with Voice and Displaced Unionism," China Information 31, no. 2 (2017): 155-75; Jay Chen, "Zhongguo weiquan zhengti xia de jiti kangyi: Taizichang dabagong de anlifenxi" [Protest mobilization in an authoritarian regime: The case of a wildcat strike in southern China], Taiwan Shehuixue 30 (2015): 1-53; Chunyun Li and Mingwei Liu, "A Pathway to a Vital Labour Movement in China? A Case Study of a Union-Led Protest against Walmart," in China at Work: A Labour Process Perspective on the Transformation of Work and Employment in China, ed. Mingwei Liu and Chris Smith (London: Palgrave Macmillan, 2015), 281-311. 
( fuwuxing 服务型) and “rights protection-type” (weiquanxing 维权型) organizations into "labor movement-type" (gongyunxing 工运型) organizations. ${ }^{5}$ It was in the middle of this transition from individual legal mobilization to collective labor struggles that, in December 2015, at the end of a particularly gloomy year for Chinese civil society, ${ }^{6}$ the authorities in Guangdong stepped in and rounded up two dozen labor NGO activists, formally charging five of them with "gathering a crowd to disrupt public order" and "embezzlement." At the national level, in April 2016 the Law on the Management of Foreign Non-Governmental Organizations' Activities within Mainland China (hereafter, Foreign NGOs Law) was passed. The new law is aimed, among other things, at curtailing access to foreign funding by grassroots NGOs working in sensitive fields, including labor issues. ${ }^{7}$ Taken together, these events have proven that the "red line" of what is not allowable has shifted once again since 2015, leading Chinese labor NGOs to question and readjust their strategies. Thus, as we will highlight in the last section of this article, some have gone back to the relatively safer options of engaging in "legal mobilization" for individual workers, while others have reinvented themselves in the field of corporate social responsibility. Those that continue to carry out collective bargaining screen their cases increasingly carefully, explicitly warn workers about the possible risks, and stay clear of disruptive events or train workers far away from their workplace.

This article focuses specifically on those labor NGOs that-to resort to Duan Yi's categorization-belong to the "rights protection" and "labor movement" types. While the boundaries between these kinds of organizations are often blurred, as NGOs simultaneously engage in different kinds of activities, we do not take into account those organizations that exclusively organize cultural activities and services for workers. The article analyzes the consequences of state repression not only for Chinese labor NGOs as organizations but also for the NGOs' employees. In particular, we examine how repression operates both in its everyday form and during crackdowns and how individual labor NGO activists and their organizations respond.

5. Yi Duan, "Gongyunxing laogong NGO de qianjing yu tiaozhan" [Prospects and challenges for labor NGOs of the labor movement type], Gongmin, May 20, 2015, accessed December 13, 2017, https:// xgmyd.com/archives/17927.

6. For example, July 2015 witnessed a crackdown against weiquan lawyers that saw the disappearance and detention of hundreds of lawyers all around China. See Susan Trevaskes and Elisa Nesossi, "The Fog of Law," in China Story Yearbook 2015: Pollution, ed. Geremie R. Barmé, Linda Jaivin, and Jeremy Goldkorn (Canberra: Australian National University Press, 2016), 64-85.

7. Ivan Franceschini and Elisa Nesossi, "The Foreign NGOs Management Law: A Compendium," in Made in China Yearbook 2016: Disturbances in Heaven, ed. Ivan Franceschini, Kevin Lin, and Nicholas Loubere (Canberra: Australian National University Press, 2017), 60-67. 
Western scholars studying social movements have explored the relationship between repression and rights activism. ${ }^{8}$ In this context, studies focusing on nondemocratic countries have demonstrated that in such political systems repression does not necessarily produce predictable outcomes. Empirical analyses have produced conflicting accounts and there is no consensus on the consequences of repression for dissent. Some studies have explained that repression can generate fear that quells contention; others, on the contrary, argue that repression triggers a level of anger and outrage that fuels mobilization. ${ }^{9}$

This literature can provide a framework for examining Chinese labor NGOs. Little has been written specifically on the repression of such NGOs by the Partystate, and, more broadly, there is scant literature thus far that examines developments in the aftermath of crackdowns against civil society in Xi Jinping's China. In a study based on extensive ethnographic research in 2009-10-well before Xi came to power-Diana Fu considers how the Party-state exerts everyday control over labor organizations. ${ }^{10}$ There she argues that everyday state control under $\mathrm{Hu}$ Jintao's leadership was fragmented and heterogeneous, with bureaucratic decentralization and interagency conflicts producing "simultaneous and incongruous forms of control" that both contained and facilitated grassroots activism. ${ }^{11}$ In a more recent article in The China Journal comparing the $\mathrm{Hu}$ and $\mathrm{Xi}$ eras, Diana $\mathrm{Fu}$ and Greg Distelhorst explain how repression has shifted from being reactive to mass incidents to instead taking proactive actions to contain contention before it

8. Sabine Carey, “The Dynamic Relationship between Protest and Repression," Political Research Quarterly 59, no. 1 (2006): 1-11; Donatella Della Porta, Social Movements, Political Violence and the State (Cambridge: Cambridge University Press, 1995); Jennifer Earl and Sarah Soule, "The Impact of Repression: The Effect of Police Presence and Action on Subsequent Protest Rates," Research on Social Movements, Conflict and Change 30 (2010): 75-113; Charles Tilly, From Mobilization to Revolution (Englewood Cliffs, NJ: Prentice-Hall, 1978).

9. Terry Boswell and William J. Dixon, "Marx's Theory of Rebellion: A Cross-National Analysis of Class Exploitation, Economic Development, and Violent Revolt," American Sociological Review 58, no. 5 (1993): 681-702; Charles Brockett, “A Protest-Cycle Resolution of the Repression/Popular Protest Paradox," Social Sciences History 17, no. 3 (1993): 457-84; James de Nardo, Power in Numbers (Princeton, NJ: Princeton University Press, 1985); Marwan Khawaja, "Repression and Popular Collective Action: Evidence from the West Bank," Sociological Forum 8, no. 1 (1993): 47-71; Marwan Khawaja, "Resource Mobilization, Hardship, and Popular Collective Action in the West Bank," Social Forces 73, no. 1 (1994): 191-220; Mark Lichbach, "Deterrence or Escalation? The Puzzle of Aggregate Studies of Repression and Dissent," Lournal of Conflict Resolution 31, no. 2 (1987): 266-97; Mark Lichbach, The Rebel's Dilemma (Ann Arbor: University of Michigan Press, 1995); Edward Muller, "Income Inequality, Regime Repressiveness, and Political Violence," American Sociological Review 50, no. 1 (1985): 47-61; Johan Olivier, "State Repression and Collective Action in South Africa, 1970 to 1984," South African Journal of Sociology 22, no. 4 (1991): 109-17; Mancur Olson, The Logic of Collective Action (Cambridge, MA: Harvard University Press, 1965); Neil Smelser, Theory of Collective Behavior (London: Routledge \& Kegan Paul, 1962); Kurt Schock, Civil Resistance Today (Cambridge: Polity, 2015); David Snyder and Charles Tilly, "Hardship and Collective Violence in France, 1830-1960," American Sociological Review 37, no. 5 (1972): 520-32.

10. Diana Fu, "Fragmented Control: Governing Contentious Labor Organizations in China," Governance: An International Journal of Policy, Administration and Institutions 30, no. 3 (2017): 445-62.

11. Ibid., 447. 
occurs. ${ }^{12}$ We agree with Fu and Distelhorst when they argue that repression does not generate predictable outcomes and that in the Chinese political context it does not necessarily produce intended results. Indeed, according to our experience, while repression can potentially lead to the weakening or disappearance of activism, it can also further motivate activists to pursue tactical innovations in order to keep up their work.

More specifically, our findings show that repression in the form of "rough" threats of violence, eviction, and criminal punishment has only a partial "chilling effect" on the determination of individual labor activists and on the operations of labor NGOs. In contrast, more "sophisticated" strategies of repression and control-for instance, the adoption of new laws and regulations that increase bureaucratic control over NGOs and severely limit their access to funding-have far more serious consequences at both an individual and an organizational level. As we mention later in the article, just until few years ago, repression was able to spur activism. For instance, according to the estimates provided by our interviewees, after the wave of repression of 2012, labor NGOs in Guangdong increased in number, and some of them, rather than falling silent, started to engage with collective bargaining. Today the situation has changed dramatically. Our study highlights that the very survival of labor NGOs in China is in peril exactly because the Party-state's strategies of repression have evolved and shifted in form from an approach based mostly on violence and threats to a more nuanced strategy that integrates violence and threats with more sophisticated tools like legal intimidations and funding curtailment. In Xi Jinping's China, labor organizations are seriously struggling to carry out their work without reliable sources of income. They are also making a series of strategic adjustments to their approach, changes that not only water down the role that these organizations play among the workers but also reveal the fragile nature of this community of activists.

In addition to this introduction and a conclusion, the article is organized in four sections. In the first section, we describe the everyday methods the authorities adopt to keep labor NGOs in check, paying particular attention to the peculiar multifaceted relationship that binds labor NGO activists to their official controllers within the state security apparatus. In the second, we present the facts related to the latest crackdown and explain how these events present a significant break with previous state-sponsored attacks against labor NGOs. In the third, we analyze how state repression influences labor activists' subjective outlook on their work and their future. In the fourth we consider the impact of the latest crackdown on the strategies and priorities of labor NGOs.

12. Diana Fu and Greg Distelhorst, "Grassroots Participation and Repression under Hu Jintao and Xi Jinping,” China Journal, no. 79 (January 2018): 100-122. 
The article is based on fieldwork in China that one of the authors conducted from January 2009 to August 2016. Over this period, he observed the implementation of eight international cooperation projects aimed at promoting the rights of Chinese migrant workers as a consultant to the project manager. These initiatives relied on collaboration between an international labor NGO and nine different Chinese labor NGOs (three of which were branches of the same organization). Besides taking part in the project activities and monitoring the financial situation of the various projects, the author as an independent researcher conducted several dozen semi-structured interviews with leaders and employees of labor NGOs. In a first round between 2009 and 2011, 30 leaders and employees of 16 different labor NGOs, mostly based in Shenzhen, were interviewed. During the second round in 2014-15, interviews were conducted with 32 activists in 19 labor NGOs in Guangdong province in the cities of Shenzhen, Dongguan, Guangzhou, and Huizhou, as well as some areas in Hunan, Zhejiang, and Shandong provinces. The final round was in August 2016, when, due to the difficult political situation, he was able to conduct interviews with only 11 activists from 10 labor NGOs in Shenzhen, Guangzhou, Dongguan, and Nanjing. In total, over the years he interviewed 62 people from 29 different NGOs, a dozen of whom were key informants who were interviewed more than once.

\section{THE ROUTINE OF STATE CONTROL}

Borrowing from $\mathrm{Fu}$, "fragmented control" means that in their everyday operations labor NGOs have to deal simultaneously with several state bodies. ${ }^{13}$ In those relatively rare instances in which they are properly registered as nonprofit entities, they fall under the supervision of the Department of Civil Affairs (minzheng bumen 民政部门); ${ }^{14}$ while carrying out activities among workers on strike they often find themselves face-to-face with the police; and in addressing workers' ordinary grievances they communicate with the state's labor offices (laodong bumen 劳动部门). ${ }^{15}$ Still, given the reliance of many labor NGOs on foreign funding and the political sensitivity of labor issues, the agency they have the most fraught dealings with is the secretive "state security" (guobao 国保), a branch of the government's security apparatus charged with protecting the country from domestic political threats. Similar to other types of activists in China, they receive summonses

13. Diana Fu, "Fragmented Control: Governing Contentious Labor Organizations in China," Governance: An International Journal of Policy, Administration and Institutions 30, no. 3 (2017): 445-62.

14. In some local jurisdictions, labor NGOs are allowed to register with the local departments of civil affairs as "social enterprises." Still, many labor activists believe there are advantages in having a commercial registration (administered by the department of industry and commerce) or not having any registration at all.

15. Sean Cooney, Sarah Bidduph, and Ying Zhu, Law and Fair Work in China (New York: Routledge, 2013), 126 
to “have a cup of tea" (he cha 喝茶) with state security officials—a form of “soft repression" as Fu defines it. ${ }^{16}$ The frequency of these gatherings-which sometimes take place in informal settings such as a McDonald's-depends on the political circumstances: it usually intensifies on the occasion of politically sensitive events but then declines in quiet times, down to one meeting every several months.

Although state security officials can "joke with you one moment, and then get violent the next," as an NGO employee observed in 2016, these encounters usually take place in an atmosphere of mutual understanding. The meetings serve a twofold purpose. On the one hand, officials seek information about the activities of labor NGOs, in particular regarding recent contacts with foreigners and any new source of funding. On the other, they use the meetings to subtly warn, inform, or remind activists about boundaries that they must not cross if they want to avoid severe repercussions. From this point of view, the gatherings can be considered mutually beneficial: the Party-state gets to remind labor activists that they are under surveillance, while activists benefit by finding out what is already officially known about them and what the current priorities of the authorities are, and through this they are able to avoid unnecessary risks. The symbiotic nature of such a relationship emerges clearly from this testimony of a labor NGO activist in 2016:

When we talked, the people from state security even said that they support our activities to protect the rights of fellow workers. The main problem is that the upper levels put pressure on them, so they have asked us to ring them up anytime we do something. That way they can be ready in their minds. This is because if something happened and the upper levels heard about it without any prior knowledge, they would get a lot of heat, which in turn would lead them to put pressure on us. For this reason, since 2016 we have slightly changed our strategy. Now when fellow workers seek our help, after understanding the situation we report to them-it doesn't matter if it is the state security or the social stability maintenance system. We tell them that in such and such a place there are some workers who have already presented some demands to factory management and that they came to seek our help. If we decide to get involved, we inform them first.

Various NGO activists confirmed that this kind of relationship can also offer some perks. One of them told us in 2016 that "sometimes [state security officials] also offer us some gifts, for instance, shopping coupons, which obviously we don't accept.... But it seems that in recent years they've become poorer, they don't have as much money as before." In another instance, an activist told us that in 2012, while he was recovering in the hospital from surgery, the state security official

16. Fu, "Fragmented Control," 450. 
in charge of him had paid him a visit. Wishing him a speedy recovery, the guobao agent had brought him flowers and had engaged him in conversation. The activist explained that, since this official had been supervising him for quite some time, they had almost become friends, regularly exchanging greetings and wishes during all major festivities. One of the authors had direct experience of this ambiguous relationship between labor activists and state security on several occasions. For instance, in 2009 or 2010 he was managing a project in partnership with a labor NGO that was engaging in fake activities and handing in inflated invoices. When the author refused to reimburse some obviously dodgy expenditure, the leader of the labor NGO hinted that he would say something unpleasant about the author in his next meeting with state security.

In authoritarian China, the distinction between politically sensitive or even hostile activities and acceptable activities has always been fluid. ${ }^{17}$ This means that activists have to rely on disparate sources of information to understand where to draw the "line of acceptability." ${ }^{18}$ Our interviewees related that the peculiar relationship established with state security allows labor NGO activists to better understand the "bottom line" (dixian 底线) that they are not supposed to cross. It is exactly such an understanding that permits labor NGOs to play a role in strikes and protests in relative safety, as long as they respect certain preconditions, such as making sure that the workers do not leave the factory premises, do not organize across workplaces, and do not leak news of their protests through social media. Unfortunately, the guarantees offered by the state security sometimes prove illusory. For instance, after being repeatedly evicted from his office, a labor activist was told by state security officials that the harassment would cease if he stopped accepting foreign funding. To test this, he decided to stop a project on collective bargaining funded by a foreign NGO. After a few months, realizing that this decision did not make any difference, he decided to resume cooperating with international donors. ${ }^{19}$

When a crackdown is looming, invitations from state security officials cease, and instead of dealing with the "reasonable" face of the Party-state, activists are left facing much less sympathetic agencies-from the "ordinary" police to the offices in charge of taxation and safety in the workplace. The peculiar and at times very personal and ambiguously friendly relationship established between activists and state security officials leads some activists to shift the blame for repression onto other Party-state institutions that carried out the crackdowns. This attitude may explain why, in spite of the attacks that some labor activists were subjected to in late 2015, some of the labor NGO leaders whom we interviewed half a year later paradoxically explained that their relationship with the state security officers was

17. Sebastian Heilmann, ed., China's Political System (Lanham, MD: Rowman \& Littlefield, 2016), 273.

18. Fu, "Fragmented Control," 453.

19. Franceschini's interview with labor activist, 2016. 
improving, as the guobao apparently had become "more understanding and approving of our activities." 20 The fragmentation of the Chinese control apparatus appears to be instrumental, as it not only allows the Party-state to maintain its control over labor NGOs in ordinary times but also assists the authorities in maintaining a semblance of normalcy even during the worst crackdowns.

\section{A CONTINUOUS CRACKDOWN}

Since the 1990s, crackdowns have been a periodic feature in the bumpy relationship between the Party-state and labor NGOs. Still, until 2012, repression occurred in cycles, typically coinciding with major events such as National Day on October 1 or a Party congress or in the wake of particular serious strikes or "mass incidents." The year 2012 was a turning point for the Chinese leadership, with then President $\mathrm{Hu}$ Jintao retiring and Xi Jinping rising to power, a transfer that also marked a shift in governance platforms and approaches to civil society activism. Under the leadership of $\mathrm{Hu}$ Jintao and Wen Jiabao (2002-12), the Chinese state's repressive apparatus was complicated, ${ }^{21}$ nevertheless, civil society was allowed some space to operate in order to offer services that the state was not able to provide, all the while being kept under scrutiny because of the alleged threat to social stability (shehui wending 社会稳定). ${ }^{22}$ Civil society organizations could operate in the interstices created by a "fragmented authoritarian state" and were kept in check through forms of " control." 23 Since 2013, Xi Jinping has made "governing the nation according to the law” ( yifa zhiguo 依法治国) a key governance platform, emphasizing the role of the legal system as a tool of social and political control. What we observed in our research is that in Xi's China, the authorities are using the law to exercise everyday control, closing those "policy windows" opened up by the "control" of Hu Jintao's leadership. ${ }^{24}$ Attacks against civil society, including labor NGOs, have become more consistent and it has become increasingly difficult to distinguish between periods of "crackdown" and more ordinary times when labor NGOs can conduct their activities without harassment.

20. The activists who felt this way put the ultimate blame for their woes on the labor bureau bureaucracy and on the official All-China Federation of Trade Unions (ACFTU) - the only union whose existence is allowed in China, a Leninist mass organization under the thumb of the CCP.

21. Gary King, Jennifer Pan, and Margaret E. Roberts, "How Censorship in China Allows Government Criticism but Silences Collective Expression," American Political Science Review 107, no. 2 (2013): 1-18.

22. Andrew Mertha, China's Water Warriors: Citizen Action and Policy Change (Ithaca, NY: Cornell University Press, 2008); Anthony J. Spires, "Contingent Symbiosis and Civil Society in an Authoritarian State," Journal of Sociology 117, no. 1 (2011): 1-45; Jessica Teets, Civil Societv under Authoritarianism: The China Model (New York: Cambridge University Press, 2014).

23. Kenneth G. Lieberthal, "Introduction: The Fragmented Authoritarianism Model and Its Limitations," in Bureaucracy, Politics, and Decision-Making in Post-Mao China, ed. Kenneth G. Lieberthal and David Lamton (Berkeley: University of California Press, 1992), 1-30; Fu, "Fragmented Control."

24. Timothy Hildebrandt, Social Organizations and the Authoritarian State in China (New York: Cambridge University Press, 2013). 
The crackdown that took place in 2012 initially seemed just another "ordinary" attack against labor NGOs. In August that year, several labor NGOs in Guangdong, especially in Shenzhen, were repeatedly and coercively evicted from their premises and forced to momentarily shut down their activities. ${ }^{25}$ Yet, while public attention to the evictions waned very quickly, this was not merely a temporary attack. For instance, one labor activist whom we interviewed in September 2015 complained that since 2013 he had been forced to move his office no less than 15 times, once every two to three months. At the time of the interview, he had spent about four months in his latest office, his longest stay in the previous two years. In another case from mid-2012, after hired thugs had attacked its office, a prominent Shenzhen labor NGO was forced to vacate its premises. In late 2014, when we met its representatives, their office was based in a hotel room and they had completely given up on the idea of opening the premises to the public. A labor NGO activist told us in November 2014: "In the past, they didn't provoke us, nor did we provoke them. Basically, the situation back then could not even be called repression. Usually, they just knew about the existence of our organization and there were people from the government who often came to talk with us. . . But these last few years have been quite different. They've started to harass us directly."

The 2012 crackdown appeared to be intimately connected with a strategy Jude Howell has referred to as the "welfarist incorporation" of labor NGOs, which was being pursued by the Party-state under the leadership of $\mathrm{Hu}$ Jintao and Wen Jiabao. Incorporation entailed a "political and economic arrangement between the state and organized society, whereby selected civic organizations are invited by the state to assist in the implementation of policy." 26 At about the same time as the evictions started, the trade union federation of Guangdong province set up the "Federation of Social Service Organizations for Guangdong Workers," an umbrella organization that included some well-known grassroots labor NGOs in addition to several industrial employer associations, university legal clinics, foundations, local trade union agencies, lawyers, and union cadres. ${ }^{27}$ Although this umbrella organization seems to have fallen into oblivion, several labor NGO activists whom we interviewed observed that the Party-state today continues to claim the space once occupied solely by labor NGOs, for instance, by promoting support to victims of labor-related injuries, a realm that before was occupied almost exclusively by labor NGOs.

25. Xiaotian Du and Renwang Zhang, "Laogong NGO: Chengzhang de fannao" [Labor NGOs: The worries of growing], Nanfang Ribao [Southern Daily], September 3, 2012.

26. Jude Howell, "Shall We Dance? Welfarist Incorporation and the Politics of State-Labor NGO Relation,” China Quarterly, no. 223 (2015): 702-23.

27. Qingyu Xie, "Sheng zonggonghui qiantou goujian shouge zhigong fuwulei shuniuxing shehui zuzhi" [The provincial union federation takes the lead in establishing the first service social organization of a transmission belt kind for workers], Nanfang Ribao, May 17, 2012. 
While the 2012 crackdown was still "traditional" in the "rough" methods adopted by the authorities-forced evictions, violence, intimidation of family members, and so on-the years that followed Xi's ascent to power saw an escalation in the tension between the Party-state and NGOs and a shift to more "sophisticated" methods of repression and control. The authorities have adopted a whole new set of laws and regulations aimed at reinforcing the control of the Party-state over civil society and severing the international ties of these NGOs, including the controversial Law on Foreign NGOs. These laws will make cooperation between foreign donors and Chinese grassroots NGOs working on politically sensitive issues extremely difficult. At the same time, the Party-state has criminally charged and convicted a number of individual activists, including those working on labor rights. As mentioned, in December 2015 the police rounded up a couple of dozen labor activists in Guangdong and brought charges against five of them. ${ }^{28}$ On that occasion, the state media systematically attacked Zeng Feiyang, the leader of the Panyu Migrant Workers Centre, a pioneering labor NGO established in Guangzhou in the late 1990s. In a long article published online on December 22, the official Xinhua News Agency accused Zeng of, among other things, embezzling funds illegally obtained from foreign donors and promoting himself as a "star of the labor movement" (gongyun zhi xing 工运之星) while acting in total disregard of the actual interests of the workers. ${ }^{29}$ To further damage his credibility, Zeng was also accused of several instances of sexual misconduct. In the following days, a report of a similar tone appeared in the People's Daily, which also mentioned the relationship between Zeng Feiyang and China Labor Bulletin, a well-known NGO based in Hong Kong led by Han Dongfang, a former worker who had played a high-profile role in the Tiananmen protest movement of 1989 and has been in exile since the mid-1990s. ${ }^{30}$ Eventually, in September 2016 Zeng Feiyang pleaded guilty and the Panyu District No. 2 People's Court sentenced him to three years' imprisonment, suspended for four years, for "gathering a crowd to disturb social order," while two of his colleagues received prison sentences of 18 months, suspended for two years, on the same charge. Another colleague refused to cooperate with the authorities but after repeated harassment of his parents he finally capitulated and pleaded guilty. In November 2016, the Panyu Court sentenced him to 21 months in jail.

\footnotetext{
28. Sui Lee Wee, "China Arrests Four Labor Activists Amid Crackdown: Lawyers," Reuters, January 10, 2016, accessed December 13, 2017, http://www.reuters.com/article/us-china-rights -idUSKCN0UO05M20160110.

29. Wei Zou, "Guangdong jingfang dadiao weiquan zuzhi ju 7 ren, zhufan bei cheng 'gongyun zhi xing"” [Guangdong police takes down a weiquan organization and detains seven people: Main culprit was "star of the labor movement"], Xinhua, December 22, 2015, accessed December 13, 2017, http://m.thepaper.cn /newsDetail_forward_1412138.

30. Cong Zhang, "Qidi 'gongyun zhi xing' zhen mianmu" [Exposing the true face of the "star of the labor movement”, Renmin Ribao, December 23, 2015, 11.
} 
This harsh treatment of Zeng and his colleagues shows clear similarities with the treatment meted out to prominent weiquan lawyers and other well-known Chinese activists targeted in a crackdown that took place a few months earlier in July 2015. They were singled out, held incommunicado, and formally arrested only after a long period of time; they were unable to meet with their choice of lawyers; their alleged crimes and collusion with "hostile foreign forces" ( jingwai didui shili 境外敌对势力) were disclosed to the public via the official media, and their staged confessions of guilt were displayed on television. ${ }^{31}$ Zeng and his colleagues' treatment was probably related to their outspokenness in several high-profile cases of labor unrest. The December Xinhua article described in considerable detail the role that Zeng's organization had played earlier that year in a high-profile collective action undertaken by workers of a footwear company in Guangzhou that was planning to relocate its factory without providing proper compensation to its employees.

The 2015 crackdown included some fundamental differences with previous waves of repression. First, earlier instances of repression against labor NGOs were local matters, whereas the attack against Zeng and other activists was publicized nationwide and was part of a concerted nationwide campaign against Chinese civil society at large. This was made abundantly clear when several national TV stations concurrently aired long accusatory segments of a very similar tone. ${ }^{32} \mathrm{Sec}-$ ond, while earlier attacks primarily used extralegal means such as intimidation, raids by hired thugs, ${ }^{33}$ and strong informal pressure on landlords to evict the NGOs, this latest crackdown mainly employed legal means. This ongoing wave of repression has made use not only of the criminal legislation but also of a set of new laws and regulations-including the Foreign NGOs Law, the Charity Law, and the Opinion on Domestic Civil Society Organizations-that address all facets of civil society and significantly reinforce the demarcation between organizations belonging to China's "official" and "unofficial" civil society, strengthening the first and weakening the latter. ${ }^{34}$ These developments suggest a more systematic approach by the Party-state aimed at remolding the relationship between state and society in China and severing the international ties of Chinese NGOs that work on politically sensitive matters, including labor issues.

31. Christian Sorace, "Extracting Affect: Televised Cadre Confessions in Contemporary China," Public Culture, forthcoming.

32. For instance, see the segments on http://news.cntv.cn/2015/12/23/VIDE1450829040823784.shtml and http://news.cntv.cn/2015/12/23/VIDE1450847339236690.shtml.

33. Lynette Ong, "Thugs and Outsourcing of State Repression in China," China Journal, no. 80 (July 2018), in this issue.

34. Mary Gallagher, "China: The Limits of Civil Society in a Late Leninist State," in Civil Society and Political Change in Asia: Expanding and Contracting Democratic Change, ed. Muthiah Alagappa (Stanford, CA: Stanford University Press, 2004), 419-54. 


\section{COPING WITH REPRESSION}

How do labor activists react to state repression at a personal, subjective level? In spite of all the pressures they are under, in our interviews throughout the years, labor NGO activists seldom expressed fears about the rough threats of violence and intimidation coming from the Party-state, not even in the wake of the worst crackdowns. Like other rights activists in China, they feel accustomed to state repression, to the point of considering it the normal state of affairs for their profession. While they are deeply aware that changes in the political structures affect their ability to work and the form that their activism can take, they remain undeterred in their motivations. It was often repeated to us in interviews that when they decided to work for a labor NGO they knew perfectly well what they had signed up to. As one labor activist told us in the summer of 2016: "What is there to be afraid of? ... I just think that I have a duty to do these things: if one day they arrest me, the people around me will know what kind of person I am." Nevertheless, the move against Zeng Feiyang and his colleagues rattled nerves and for a few months the whole sector became quiet and especially cautious. One of the most outspoken NGO leaders admitted that in the months that followed the arrests he was "terrified":

Of course I'm scared. Who's not scared of losing his freedom? It's just that personally I think that what I do is legal. It doesn't violate any law of the state.... What we do is reasonable, so why don't we dare to speak out? . . . I feel terrified in every single thing I do. In April and May we dealt with seven collective disputes. Actually, I felt so scared, but there was nothing I could do: once you have started you have to keep going. It is like when you enter a battlefield: you should not be afraid, because if you're afraid you should not be there in the first place. It's that simple. This sacrifice of mine is glorious. If you stand on a battlefield and sacrifice yourself, this is definitely glorious. ... I don't care about the pressure, because I've been doing this for ten years and I've been fully mentally prepared since the beginning.

Behind this quixotic willingness to keep struggling and these martial undertonessimilarly exhibited by other weiquan activists ${ }^{35}$ - there are pragmatic calculations about the acceptable "costs" of activism. According to this labor NGO activist, a punishment of up to three years in jail-which was exactly the length of Zeng's suspended sentence, announced several months later-was a price worth paying, especially considering that being imprisoned would increase the respect his peers felt for him. In his words, "If you really commit a crime, other people will look down on you, right? But if you do some righteous things, everybody will think that

35. Eva Pils, China's Human Rights Lawyers: Advocacy and Resistance (Abingdon: Routledge, 2015). 
you are worth respect. What I mean is that it doesn't matter if you are working outside or you are in jail, it is still work and it can have a positive significance."

In our interviews, we found that in many cases, far from having a chilling effect, "rough" repression reinforces the determination of labor NGO activists and stimulates strategic innovations that enable them to persist. As far back as the aftermath of the 2012 crackdown, Jude Howell observed that "some labor NGOs are reviewing their approach and turning towards a more movement practice that focuses on supporting local workers' groups." 36 This has translated into the new strategic focus on collective bargaining and collective labor struggles that we highlighted at the beginning of this article.

At an individual level, several of our interviewees explained how falling victim to state repression actually ended up reinforcing their motivation. For instance, in 2013 a worker who was volunteering for a labor NGO in Shenzhen was detained for joining a strike against the relocation of the company he worked for. Accused of "gathering a crowd and disrupting the order of public transportation," he spent over a year in a cell in the company of common criminals before being released for lack of evidence. In that case, the attempt to intimidate him did not work, as once released he decided to establish a labor NGO of his own. He noted in 2015: "Before being arrested, I was only a volunteer in an NGO. I had never thought about establishing my own organization, I was just motivated by the idea of serving the workers. After regaining my freedom, I had an inspiration and I thought that I might as well establish an organization myself to help even more workers."

Similarly, a young social worker who had been working for three years for a labor NGO explained in 2015:

Actually, in 2012 I was considering leaving [this NGO]. I had worked here for a few years and it was always the same stuff. Then in 2012 they evicted us, and so I felt I couldn't leave. When other NGOs were evicted from their premises, many employees left, but all of us decided to stay and the bond between us became even stronger. Soon after that, we changed the scope of our work, so now we are carrying out activities that we never did before. After 2012, I have never again thought about leaving.

Some NGO employees of worker background feel that they have no alternatives but to persist in the movement. Having been involved for years in well-funded projects and having become accustomed to being in the limelight as "saviors" of the Chinese working class, they are reluctant to return to an anonymous job in a factory-assuming that they could still get an ordinary job given their reputation as troublemakers. One such activist, who had set up his own organization using the compensation that he had received for a serious labor-related injury,

36. Howell, "Shall We Dance?," 719. 
told us in 2016: “I have to keep doing this. Honestly, I can't do anything else. . . . I haven't thought about giving up.... Before, I was a worker, and if I go back to work in a factory it will be like before."

Some other activists feel that their work with labor NGOs has stained their reputation. One told us in 2016:

I don't worry much, but my relatives do. First, after doing this job for so many years I don't have a way out, as everybody knows what I've been doing. . . . Even my former teacher doesn't have a clear idea of what are the root causes of our work. He just sees the negative reports in the media and believes that what we do goes against the Party and the government. Even after our explanations, he basically still believes that, and there's no way to convince him. He thinks that the Communist Party is very good and he says we should be grateful, that if there were no Communist Party there wouldn't be the new China and without the new China there wouldn't be this good life.

The worries about not being able to go back to a normal life and the resentment caused by their perception that they are victims of injustices at the hands of the Party-state all contribute to make labor NGO activists more determined to keep up with their work in spite of all the challenges. From this point of view, state repression-at least when the political costs of NGO activism are relatively contained-does not have a chilling effect on labor activists and at times even has a positive, inspiring effect, thus supporting some of the empirical findings related to other nondemocratic contexts that we referred to earlier in the text.

Still, in Xi's China the authorities also rely on laws and regulations that are making it difficult for labor NGOs to access those foreign funding crucial to their institutional survival. Although an attitude of "wait and see" was prevalent among labor activists in 2015 and 2016-after all, nobody could predict how strict the authorities would be in enforcing the new legislation-all our interviewees expressed serious worries about funding. This anxiety has always been there, as many labor NGOs rely on internationally funded projects to carry out their activities and, in some cases, to survive; but prior to the enactment of the Foreign NGOs Law these concerns were tempered by the knowledge that there were plenty of foreign donors willing to provide support. Today, the number of foreign donors willing (or able) to fund Chinese grassroots NGOs is dropping, and even many of the donors that are willing to continue do not know how to safely and legally transfer their money to potential beneficiaries in China. ${ }^{37}$

37. According to a recent survey, the number of foreign donors dropped nearly 40 percent from 2013 to 2015 (see Su Wang, "2015 NGO jingwai zizhufang shuliang huapo, liang nian ju jiang si xheng" [The number of foreign donors for Chinese NGOs in two years dropped by nearly 40 percent], Caixin, November 12, 2015). Our regular communications with foreign donors reveal that the Foreign NGOs Law has clearly had a 
Some are able to quietly transfer relatively small amounts of funding from abroad in cash or using other ploys, but larger amounts have become almost impossible. One of the authors had direct experience of this when, in 2015-well before the new legislation on foreign NGOs was passed-one of the EU-funded projects that he was coordinating had to be suspended because the bank where the local partner NGO held an account refused to change the funding in foreign currency into RMB. Despite the assistance provided by European officials, the local NGO had no choice but to give up the project and return all the funding, and as a consequence it faced a financial crisis that threatened its existence. In 2016, for the first time in many years, at the end of an interview one of the authors was asked by a Chinese labor NGO activist to wire some money- "really, any amount matters"- to the bank account of one of his friends. Having been barred from accessing money from abroad directly, he had not received any funding for more than four months.

Our interviews revealed that a lack of funding has a chilling effect far more serious than the risk of being arrested and jailed. As one activist reported in 2016: "The biggest trouble that we are currently facing is funding. If we had enough funding, we could still keep going. The pressures related to our work are nothing new, they were always there." Another activist noted in 2015: "Funding is the biggest problem. We can deal with pressure from the government through personal connections or by [shifting] our standpoint, but if you don't have funding there is nothing you can do."

\section{OPERATIONAL ADJUSTMENTS}

How did the shift in the techniques of state repression and control affect the operations of the Chinese labor NGOs under Xi Jinping? Our interviews reveal three main trends: atomization, strategic changes, and weakened solidarity. The first development-atomization-is in no way an unavoidable consequence of state repression. In 2014 and 2015, most interviewees stated that the number of labor NGOs in China had grown since 2012-a particularly ominous year of political repression-but their organizations had become smaller in size in order to escape official scrutiny and pressure. Significantly, the new organizations were mostly founded by activists of NGOs that had fallen victim to state repression. Even after beginning to work independently, these activists had remained on friendly terms with each other, a development that in the long run may have ended up fostering solidarity and trust among organizations, laying the foundations for a

\footnotetext{
"chilling effect" on them. Before the legislation came into force, representatives of foreign organizations displayed a "wait and see" attitude, amid the uncertainties concerning their status within the country. Some were considering diverting their donations to less politically challenging environments where projects could be carried out with fewer risks.
} 
tighter network. ${ }^{38}$ But a couple of years later, the NGOs were struggling to barely survive due to the lack of funding, and even small organizations were on the verge of disappearing. In 2016, several activists who had worked in labor NGOs for more than a decade felt compelled to leave, arguing that their organizations had become basically useless. A number of them continue to provide services on an individual basis as "barefoot lawyers" or "civic agents" (gongmin daili 公民代理), ${ }^{39}$ and others work individually in worker communities. One interviewee confided in 2016: "We've entered a grey area: we're not organizations anymore, and maybe in the future we'll be reduced to only a few individuals".

Labor NGO activism has always been a risky matter, and this has led to some readjustments in the work of labor NGOs. Today, only a few labor NGOs still assist workers who are on strike to organize to demand collective bargaining. A great majority of the labor NGOs prefer to limit themselves to the relatively safer option of "legal mobilization" or to carry out simple cultural activities, or they have even reinvented themselves as entrepreneurs in the field of corporate social responsibility. Those that still promote collective bargaining carry out their activities with a heightened feeling of danger and only after having undertaken some strategic readjustments. First, they screen their cases more carefully. As one activist told us in 2016, the NGO he was working for used to accept almost every case that had been reported to them, but now "when we encounter a situation, we have to understand where the risks lie and what are the dangers if our organization gets involved." Second, they feel obliged to warn workers about the risks they face if they decide to follow their advice: "We need to be more careful. When we carry out some training for workers, we have to inform them that weiquan [rights protection] is dangerous." Finally, instead of rushing to the scene whenever a strike or a collective protest erupts to advise workers on how to proceed, they now tend to steer clear of disruptive events and focus on training workers in locations far from their workplace.

A third trend is that solidarity among labor NGOs is weakening. While intuitively we would have expected labor NGOs to coalesce in the face of a common challenge, the dearth of funding seems to be pitching labor NGOs against each other. One NGO activist told us in 2016:

Right after the detention of Zeng Feiyang and the other labor NGO activists, the contacts among NGOs increased, and everybody used to discuss this all the time, but when the feeling of danger attenuated everything went back to the way it was

38. Ivan Franceschini, "Revisiting Chinese Labour NGOs: Some Grounds for Hope?," in Franceschini et al., Made in China Yearbook 2016, 46-49.

39. Aaron Halegua, "Who Will Represent China's Workers? Lawyers, Legal Aid, and the Enforcement of Labor Rights," U.S.-Asia Law Institute, New York University School of Law, 2016, accessed December 13, 2017, https://papers.ssrn.com/sol3/papers.cfm?abstract_id $=2845977$. 
before. This is because we don't have a common way of thinking [zhuti sixiang 主 题思想]. Moreover, NGOs now are quite scattered, they all are single organizations following different directives favored by their donors. Maybe it's for this reason that there are some suspicions between organizations and that there are conflicts of interest or contradictions. It's unavoidable.

Another labor NGO activist said that he hoped the new legislation on NGOs would have one positive repercussion-exposing those labor NGOs that "existed only for the sake of scraping by," as opposed to those that shared his beliefs and values. This lack of solidarity was nowhere more evident than in an incident that took place in mid-2016. When, in May, Walmart announced its intention to implement a new flexible scheduling system across its retail stores in China and asked each of its employees to sign a declaration agreeing to the new system, ${ }^{40}$ there was significant opposition by an informal group of Walmart employees, the Walmart Chinese Workers Association (WCWA, 沃尔玛中国员工联谊会), an online network founded by several current and former Walmart employees. ${ }^{41}$ The online discussions led to a wave of strikes and other forms of protest in Walmart stores all over the country. In the midst of these, a couple of labor NGOs based in Guangdong province entered the fray, trying to secure a leading role in the protest and criticizing the WCWA founders for being too timid in their dealings with the company. One labor NGO leader-whom some of our interviewees believed to be motivated by the demands of a foreign donor-went so far as to encourage Walmart workers to set up a new group that would attempt to force the company to the bargaining table. This led to a series of public exchanges of spiteful mutual accusations on blogs and NGO chat groups between the founders of WCWA and the intervening labor NGOs. In turn, this caused a split among the Walmart workers, with some taking one side and some the other, a development that several activists deemed even more damaging than state repression.

\section{CONCLUSION: A POINT OF NO RETURN?}

After two decades of operation, are Chinese labor NGOs approaching a point of no return? To what extent are the ebbs and flows of repression shaping labor activism in China? Sophisticated legal and financial means of repression have created a situation in which the possibility of continued NGO mobilization has weakened. While labor NGO activists in China are familiar with and not easily

40. In contrast to the current standard eight-hour working day for full-time workers, with the new system Walmart would have been able to schedule any number of hours, as long as they added up to 174 hours per month. The new system would have reduced workers' overtime pay and introduced an erratic work schedule.

41. Anita Chan, "The Resistance of Walmart Workers in China: A Missed Opportunity," in Franceschini et al., Made in China Yearbook 2016, 50-55, available as open access on the web. 
intimidated by violence, threats, and other rough forms of state repression, they are more vulnerable when it comes to more sophisticated and legalized forms of control, such as regulations targeting their sources of income.

Until recently, Chinese labor NGOs were able to steer through cyclical crackdowns by exploiting the partial protection offered by their ambiguous relationship with state security personnel in the interstices of authoritarian control. Thus, repression did not mute them but rather, similar to other communities of activists within China, encouraged organizational shifts and individual self-reflection, with some NGOs changing their mission and strategies-for instance, by embracing collective bargaining-and NGO employees questioning themselves about their individual drives, commitment, and aspirations.

Under Xi Jinping, Chinese authorities no longer appreciate the benefits that labor NGOs may bring to social order and stability, and they are determined to weaken their operations. They know that the most effective way to do that is through the enactment of laws. In accordance with Xi's "governing the nation in accordance to the law" platform, criminal legislation is being employed to incriminate individual labor activists, while the legislation governing NGOs is being used to curtail potential sources of international funding. Even though some foreign funding still manages to reach the NGOs and to support their activities, the new laws make it extremely difficult to transfer money to the organizations in a straightforward way, especially considering that most of the labor NGOs do not have any official registration in mainland China.

As noted in this article, the labor NGOs have responded to the more sophisticated strategies of repression by the Party-state not by strengthening their existing networks and alliances but by becoming increasingly isolated and atomized. While in the very short term this shift toward atomization makes sense to labor NGOs as a strategy of survival, in the long term these developments threaten the very existence of these organizations in China. Under increasing assault, the isolated, atomized, and impoverished NGOs that survive Xi's repression "according to the law" will have no other choice than to adjust. They can either do so by changing the scope of their mission-for instance, by subordinating themselves to the authorities and focusing on less sensitive activities such as those related to corporate social responsibility—or by abandoning any semblance of formal organization and going underground to operate as individual activists. If they fail to do so, they might have to rely on the "generosity" of the Party-state more than ever before in the hope of being granted some space to operate. 